\title{
Reproductive parameters of dairy goats submitted to estrus synchronization with prostaglandin F2 $\alpha$ associated or not to hCG at estrous onset
}

\author{
[Parâmetros ovarianos de cabras leiteira submetidas a sincronização do estro com protaglandina \\ F2 $\alpha$ associada ou não ao hCG no início do estro] \\ L.V. Esteves ${ }^{1}$, F.Z. Brandão ${ }^{1}$, R.C. Cruz ${ }^{2}$, J.M.G. Souza ${ }^{3}$, E. Oba ${ }^{4}$, O. Facó ${ }^{5}$, J.F. Fonseca ${ }^{5 *}$ \\ ${ }^{1}$ Faculdade de Veterinária - Universidade Federal Fluminense Federal - Niterói, RJ \\ ${ }^{2}$ Universidade Federal de Viçosa - Viçosa, MG \\ ${ }^{3}$ Unversidade Estadual do Ceará - Fortaleza, CE \\ ${ }^{4}$ Universidade Estadual de São Paulo - Botucatu, SP \\ ${ }^{5}$ Embrapa Caprinos e Ovinos - Sobral, CE
}

\begin{abstract}
The objective of this study was to evaluate the efficiency of two doses of PGF associated or not to hCG on the associated reproductive parameters in dairy goats. A total of 29 goats received two doses of $30 \mu \mathrm{g}$ d-cloprostenol latero-vulvar at a 10 day intervals (Day 1 and Day 10). The does were allocated according to body weight and body condition score into two treatments, to receive hCG (250IU) or saline at estrus onset. After the second dose of PGF, estrus was monitored and ultrasound exams were performed twice daily. All does were inseminated $16 \mathrm{~h}$ after estrus onset. Blood collection was performed every day for progesterone assay. The use of hCG at estrus onset did not affect any studied parameter and therefore the data were pooled. Estrous response rate was similar $(\mathrm{P}>0.05)$ after the first $(75.9 \%, 22 / 29)$ and the second dose of PGF $(79.3 \%, 23 / 29)$. The interval between the administration of PGF and estrus onset was greater $(\mathrm{P}<0.05)$ after Day $1(75.8 \pm 53.9 \mathrm{~h})$ than Day $10(47.7 \pm 10.1 \mathrm{~h})$. Estrus duration was superior $(\mathrm{P}<0.05)$ after Day $1(35.4 \pm 15.9 \mathrm{~h})$ to Day $10(26.8 \pm 15.0 \mathrm{~h})$. Ovulation rate was $79.3 \%(23 / 29)$ after the second dose of PGF. No differences $(\mathrm{P}>0.05)$ between both experimental groups were detected in the following parameters, averaging: the interval from the second dose administration to the ovulation $(86.6 \pm 11.4 \mathrm{~h})$, interval from estrus to ovulation $(39.9 \pm 12.3 \mathrm{~h})$, diameter of largest follicle $(7.2 \pm 1.4)$ and number of ovulations (1.8 \pm 0.6$)$. At Day 1, 52.4\% (11/21) of does presented progesterone concentrations $<1 \mathrm{ng} / \mathrm{mL}$. At Day $10,100 \%$ of the animals presented concentrations $>1 \mathrm{ng} / \mathrm{mL}$. The results of the present study indicate that estrus can be efficiently synchronized in dairy goats with the use of two doses of PGF at a 10 day interval. Further research should be done evaluating hCG use in different doses or moments of administration.
\end{abstract}

Keywords: Artificial insemination, d-cloprostenol, estrus synchronization, goats, sexual behavior

\section{RESUMO}

O objetivo deste estudo foi avaliar a eficiência do uso de duas doses de PGF associadas ou não à administração de hCG no início do estro sobre os parâmetros reprodutivos de cabras leiteiras. Um total de 29 cabras receberam duas doses de $30 \mu \mathrm{g}$ d-cloprostenol pela via latero-vulvar com 10 dias de intervalo (Dia 1 e Dia 10). As cabras foram alocadas para receberem o hCG (250 IU) ou salina i.m. no momento em que o estro foi detectado. Depois da realização da segunda dose de PGF, o estro foi monitorado e exames ultrassonográficos foram realizados duas vezes ao dia. Todas as fêmeas foram inseminadas $16 \mathrm{~h}$ após o inicio do estro. Amostras de sangue foram coletadas diariamente para determinação das concentrações plasmáticas de progesterona. O uso do hCG no momento do início do estro não afetou os parâmetros estudados e, portanto, os dados serão apresentados agrupados. A taxa de

Recebido em 16 de julho de 2012

Aceito em 7 de maio de 2013

*Autor para correspondência (corresponding author)

E-mail: jeferson.fonseca@embrapa.br 
manifestação de estro foi similar $(P>0,05)$ na primeira $(75,9 \%$ - 22/29) ou na segunda dose de PGF (79,3\% - 23/29). O intervalo entre a administração de PGF e o início do estro foi maior $(P<0,05)$ no Dia $1(75,8 \pm 53,9 h)$ que no Dia $10(47,7 \pm 10,1$ h). Duração do estro também diferiu $(P<0,05)$ 35,4 $\pm 15,9$ (Dia 1) vs 26,8 \pm 15 , 0 h (Dia 10). A taxa de ovulação foi 79,3\% (23/29) após a segunda dose $P G F$. Não foi encontrada diferença $(P>0,05)$ entre os grupos experimentais quanto aos parâmetros reprodutivos: intervalo entre a aplicação da segunda dose e a ovulação $(86,6 \pm 11,4 \mathrm{~h})$, intervalo do estro a ocorrência da ovulação $(39,9 \pm 12,3 \mathrm{~h})$, diâmetro do maior folículo $(7,2 \pm 1,4)$ e número de ovulações $(1,8 \pm 0,6)$. No Dia 1, 52,4\% (11/21) apresentavam concentrações de progesterona < $1 \mathrm{ng} / \mathrm{mL}$. No Dia 10, $100 \%$ dos animais apresentavam concentrações $>1 \mathrm{ng} / \mathrm{mL}$. O presente estudo permite concluir que o estro pode ser eficientemente sincronizado em cabras leiteiras com duas doses de PGF intervaladas em 10 dias. Novas pesquisas devem se realizadas para avaliar diferentes doses e momentos de utilização do $h C G$.

Palavras-chave: inseminação artificial, d-cloprostenol, sincronização do estro, cabras, comportamento sexual

\section{INTRODUCTION}

Depending on latitude and breed goats are seasonal breeders. The brazilian territory consists of a wide variety of latitudes $\left(5^{\circ} 16^{\prime} \mathrm{N}\right.$ to $\left.33^{\circ} 45^{\prime} \mathrm{S}\right)$, strongly or weakly influencing goat reproduction. In Southeastern Brazil, commercial dairy systems using specialized dairy breed regularly must induce or synchronize estrus in order to obtain a good amount of milk throughout the year. In anestrous goats, a combination of progestagens, gonadotropins and prostaglandins is the most used program to induce estrus (Souza et al., 2011). However, the use of progestagens is under review in some countries, due to issues related to public health (output of chemical residues in food, which has led to them being banned in the United States and has caused the enforcement of the regulation in maximum residue limits in the European Union) and animal welfare (causes of potential problems, such as vaginitis and/or sponge retention; Martins et al., 2009). An alternative during the ovulatory season is based on the elimination of the corpora lutea to induce a follicular phase with ovulation. The luteolytic factor in ruminants is the prostaglandin F2a (PGF); hence, administration of exogenous PGF or its analogues can be used to induce a controlled luteolysis (Reviewed by Abecia et al., 2011). We have demonstrated previously that estrus can be efficiently synchronized in Alpine and Saanen breeds using two doses of cloprostenol 10 days apart during the breeding season (Fonseca et al., 2012).

Human chorionic gonadotropin (hCG) has the alsubunit in common with the glycoprotein hormones LH, FSH and TSH. Due to the structural similarity of hCG with LH, it exerts an effect by binding to $\mathrm{LH}$ receptors. In domestic animals, hCG has a wide range of applications. It is used in the context of estrus synchronization in cattle and horses and ovulation induction in sheep and goats; but also to overcome the negative effect of premature regression of corpora lutea after superovulatory treatment in goats and to improve pregnancy rate in cattle and goats (Reviewed by Saleh et al., 2012). The objective of this study was to evaluate the effects of administering two doses of prostaglandin 10 days apart for estrus synchronization associated or not to hCG on reproductive end points of dairy goats.

\section{MATERIAL AND METHODS}

The study was conducted during the months of March and April (latitude $19^{\circ} 53^{\prime} \mathrm{S}$ and longitude $\left.44^{\circ} 25^{\prime} \mathrm{W}\right)$, corresponding to the goats' breeding season. This research was reviewed and approved by the Animal Care Committee of Fluminense Federal University (UFF/0048-2008) and it is under the ethical principles of SBCAL.

The goats were kept in an intensive system, within suspended pens. Goats were fed corn silage, Pennisetumpurpureumand Saccharum officinarum as forage. Additionally, a balanced concentrate supplement was given according to their milk production (NRC, 2007). Mineralized salt (Salminas Goats ${ }^{\circledR}$, Nutriplan, Juiz de Fora, MG, Brazil) and drinking water were available ad libidum. 
Twenty-nine pluriparous lactating dairy goats (10 Toggenburg, 10 Alpine and 9 Saanen does) were selected and allocated according to body weight (BW) and body condition score (BCS, range 1 to 5; Suiter, 1994), respectively, into two treatments. All goats received two doses of PGF $\left(30 \mu \mathrm{g}\right.$ d-cloprostenol; Veteglan ${ }^{\circledR}$, Hertape-Calier S.A., São Paulo, Brazil) latero-vulvar at a 10 day interval (Day 1 and Day 10). Immediately at estrus detection after the second dose of PGF, the does received $250 \mathrm{IU}$ hCG $(n=15$; Vetecor $5000^{\circledR}$, Hertape-Calier, São Paulo, Brazil; $47.6 \pm 8.10 \mathrm{~kg} ; 2.9 \pm 0.3)$ i.m. or $(n=14$; $48.0 \pm 8.0 \mathrm{~kg} ; 3.0 \pm 0.3) 1 \mathrm{~mL}$ saline. All drugs were administered using a $3 \mathrm{~mL}$ syringe connected to $25 \times 7 \mathrm{~mm}$ needles.

Estrus was monitored with the use of bucks twice a day (08:00 and 16:00h), from the first dose to $96 \mathrm{~h}$ after the second dose of PGF. Females were considered to be in estrus when allowed to be mounted. After the second dose of PGF and its subsequent estrus, the mucus, i.e., vaginal discharge, and visualization were evaluated twice daily. Sterilized vaginal specula were used with the aid of a lantern to observe the cervical ostium. The mucus drained from the ostium was classified into: 1- crystalline; 2- crystalline/striated; 3- striated; 4- striated/caseous; 5- caseous (Siqueira et al., 2012).

Transrectal ovarian ultrasonography was performed in all goats (by the same operator) after the second dose of PGF every $12 \mathrm{~h}$ until detection of ovulation. All examinations were conducted with a B-mode transrectal ultrasonographic scanner with 6 and $8 \mathrm{MHz}$ transducer (Pie Medical Áquila Vet ${ }^{\circledR}$, Campinas, São Paulo, Brazil). To ease the manipulation of the transducer, it was taped to a PVC tube. Does were maintained in a standing position, fecal pellets were removed manually (with a finger), and $20 \mathrm{~mL}$ of carboxymethylcellulose gel $\left(\right.$ Carbogel $^{\circledR}$, São Paulo, Brazil) were placed into the rectum with a syringe. Ovaries were located as previously described (Ginther and Kot, 1994), and the number, diameter, and position of ovarian follicles $\geq 3 \mathrm{~mm}$ were recorded. The day of ovulation was defined as the day when the largest follicle, previously identified, was no longer detected. Approximately 35d after breeding the same equipment was used to conduct ultrasonographic pregnancy diagnosis for all goats.

Artificial insemination was performed $16 \mathrm{~h}$ after the second estrus, i.e., after the second dose of PGF in all goats showing estrus up to $30 \mathrm{~h}$ after hormonal administration. Commercial frozen semen from 11 bucks of the same breeds was used. The insemination dose was $100 \mathrm{x}$ $10^{6}$ spermatozoa in $0.25 \mathrm{~mL}$ straws. The does were inseminated through the deep cervical insemination technique, with the animal in standing position (Fonseca et al., 2011). After insemination, all goats received a gentle clitoris massage for $5 \mathrm{sec}$.

Blood samples were collected in 21 goats by jugular veinpuncture into tubes containing EDTA daily from the first dose to $96 \mathrm{~h}$ after the second dose of PGF. Tubes were immediately placed in ice, transported to the laboratory, and centrifuged at $2000 \mathrm{xg}$ for $15 \mathrm{~min}$. Plasma was removed and stored at $-20^{\circ} \mathrm{C}$ pending determination of plasma $\mathrm{P} 4$ concentrations (ng/mL) with a commercial solid phase radioimmunoassay (RIA) kit (Coat-a-Count ${ }^{\circledR}$ progesterone kit, DPC, Diagnostic Products Corporation, Los Angeles, CA, USA), used according to the manufacturer's instructions.

The following data were recorded: estrous response rate (number of does in estrus up to $30 \mathrm{~h}$ after PGF doses/number of treated does $x$ 100) after the first and second dose; interval to estrus (from PGF dose to first acceptance of mounting) after the first and second dose; estrus duration (interval from the first to last acceptance of mounting); percentage of animals with diurnal estrus (number of animals observed for the first time in estrus at 16:00h/total number of females in estrus $\mathrm{x} 100)$; percentage of animals with nocturnal estrus (number of animals observed for the first time in estrus at 08:00h/total number of females in estrus x 100); interval to ovulation (interval from the second PGF dose to ovulation); interval from onset of estrus to ovulation; percentage of animals with diurnal ovulation (number of animals that had the first ovulation in the evening/total of animals that ovulated $x$ 100); percentage of animals with nocturnal ovulation (number of animals that had the first ovulation in the morning/total of animals that ovulated $\mathrm{x}$ 100); ovulation rate (number of does with confirmed ovulation/number of does 
evaluated by ultrasonography x 100); number of ovulations per doe; interval from artificial insemination to ovulation; diameter of the largest follicle (the last measurement obtained before ovulation); diameter of the second largest follicle; mucus evaluation (1 to 5); pregnancy rate (number of pregnant does/number of does inseminated).

Statistical analysis was performed using all tests with $P<0.05$ considered significant. Parametric variables were submitted to one way analysis of variance by the SAEG program (System for Statistical Analysis). Non parametric variables were analyzed using the chi-square test. Pearson correlations were calculated among the variables. The results are described as mean \pm SD.

\section{RESULTS}

There was no difference $(\mathrm{P}>0.05)$ between $\mathrm{hCG}$ or saline groups after the second dose for: interval to ovulation $(85.7 \pm 10.4$ or $87.5 \pm 12.8 \mathrm{~h})$, interval from onset of estrus to ovulation $(41.0 \pm 13.2$ or $38.8 \pm 11.9 \mathrm{~h})$, ovulation rate $[80 \%$ $(12 / 15)$ or $79 \%(11 / 14)]$, number of ovulations $(1.8 \pm 0.6$ or $1.8 \pm 0.6)$, largest follicle diameter $(6.8 \pm 0.5 ; 7.7 \pm 1.9 \mathrm{~mm})$, second largest follicle diameter $(6.2 \pm 0.5 ; 6.9 \pm 1.7 \mathrm{~mm})$ and pregnancy rate $[67 \%(8 / 12) ; 55 \%(6 / 11)]$, total of $61 \%$ $(14 / 23)$. The percentage of goats that had nocturnal or diurnal ovulations was $69.6 \%$ (13/26) and 30.4\% (7/23), respectively. All does in estrus ovulated. The mucus evaluation at the moment of AI was similar between treatments, averaging 3.0 \pm 0.4 .

The number of does in estrus after the first dose of PGF $(76 \%$; 22/29) did not differ $(\mathrm{P}>0.05)$ from those that manifested estrus after the second dose $(79 \% ; 23 / 29)$. The percentage of goats in estrus after Day 1 and 10 and the moment of its occurrence is listed in Table 1.

Table 1. Estrous response of dairy goats submitted to two doses of PGF 10 days apart after the first (Day 1) and second (Day 10) dose of PGF, according to the moment of estrus presentation (nocturnal or diurnal)

\begin{tabular}{|c|c|c|}
\hline Characteristic & & Total \\
\hline \multirow{4}{*}{ Goats in estrus Day 1} & Diurnal estrus onset & $50 \%$ \\
\hline & Nocturnal estrus onset & $50 \%$ \\
\hline & Diurnal end of estrus & $64 \%$ \\
\hline & Nocturnal end of estrus & $36 \%$ \\
\hline Total & & $76 \%(22 / 29)$ \\
\hline \multirow{4}{*}{ Goats in estrus Day 10} & Diurnal estrus onset & $91 \%$ \\
\hline & Nocturnal estrus onset & $9 \%$ \\
\hline & Diurnal end of estrus & $35 \%$ \\
\hline & Nocturnal end of estrus & $65 \%$ \\
\hline Total & & $79 \%(23 / 29)$ \\
\hline
\end{tabular}

The interval to estrus after the first dose $(75.8 \pm 53.9 \mathrm{~h})$ was longer $(\mathrm{P}<0.05)$ than after the second dose of PGF $(47.7 \pm 10.1 \mathrm{~h})$. The estrus duration was also different $(\mathrm{P}<0.05)$ for the first $(35.4 \pm 15.9 \mathrm{~h})$ or second $(26.8 \pm 15.0 \mathrm{~h})$ estrus. Of the 23 goats in estrus, $2(9 \%)$ and $21(91 \%)$ were initially identified in estrus at 08:00 (nocturnal estrus) and 16:00h (diurnal estrus), respectively.

At Day 1, 52.4\% (11/21) of the goats presented subluteal concentrations $(<1 \mathrm{ng} / \mathrm{mL})$.
Concentrations above $1 \mathrm{ng} / \mathrm{mL}$ at Day 10 were detected in all females $(100 \% ; 21 / 21)$. The does were allocated into two groups, animals that showed concentrations lower or greater than $1 \mathrm{ng} / \mathrm{mL}$ at the moment of the first and second PGF administrations. The plasma progesterone profile after the first and second dose of PGF is shown in Figure 1 and Figure 2, respectively. 


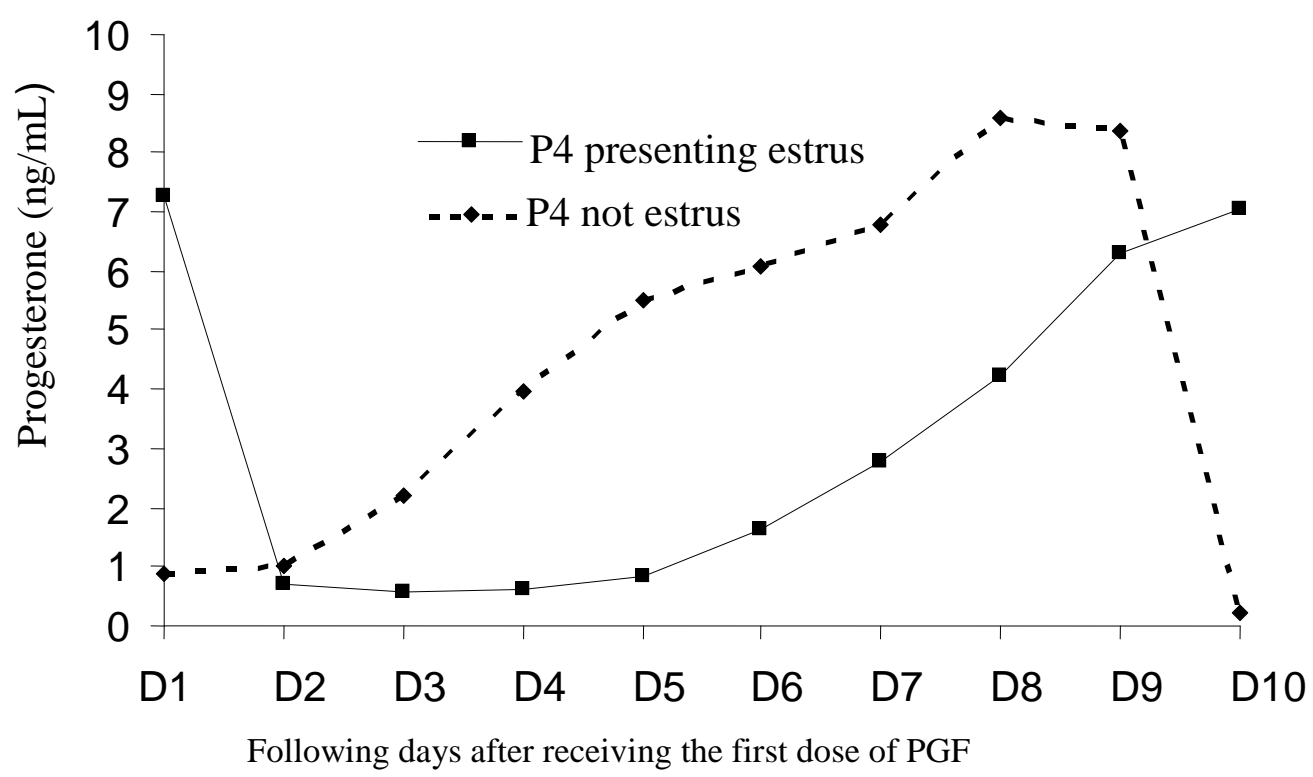

Figure 1. Plasma progesterone concentration in 21 dairy goats presenting or not estrus on the days following the first dose of PGF.

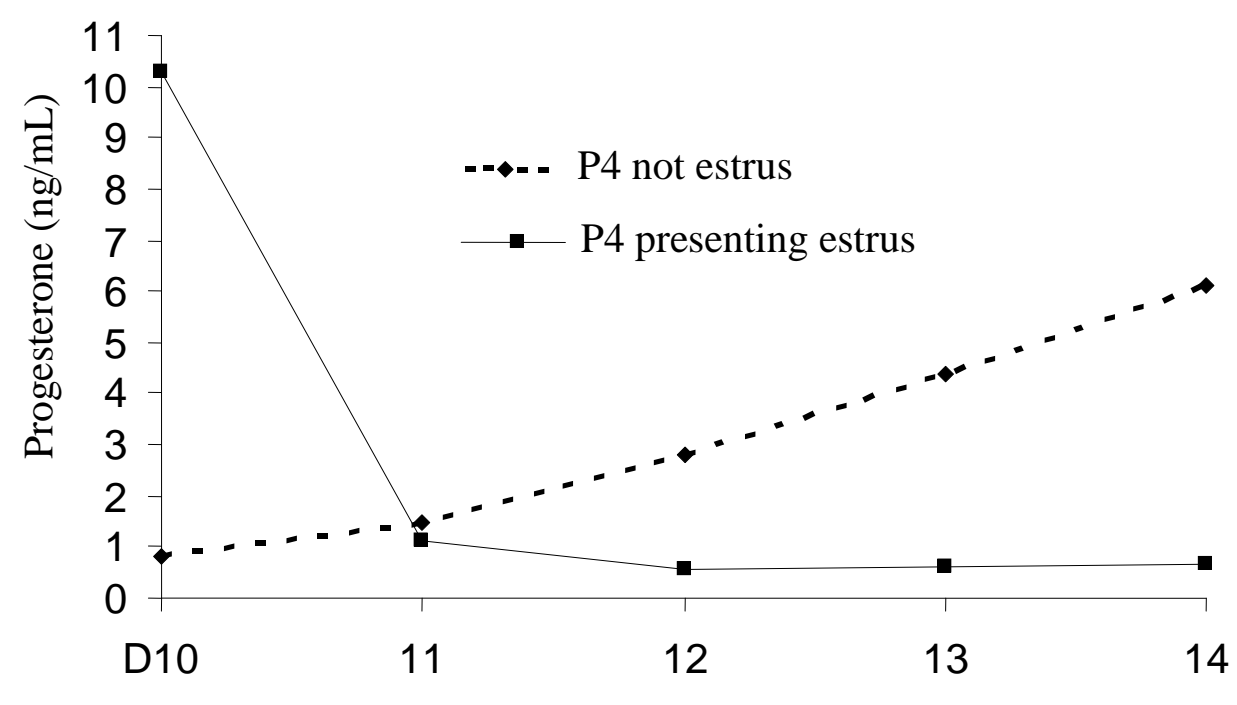

Figure 2. Plasma progesterone concentration in 21 dairy goats presenting or not estrus on the days following the second dose of PGF.

\section{DISCUSSION}

Our hypothesis was that when administering two doses of PGF 10 days apart, hCG would have benefit effects, synchronising ovulation, and than enhancing the fertility of inseminated dairy goats. Previous studies in goats had associated the use of hCG to induction acessory corpus luteum, induction of estrus (Fonseca et al.,
2006), and also to overcome the negative effect of premature regression of corpora lutea after superovulatory treatment (Saharrea et al., 1998). In goats, the plasma hCG profile following 500 IU hCG administration was characterized by rapid absorption (11.6h) and slow elimination (70.0h) (Saleh et al., 2012), different from cows, that lasted a total of 30h (Schmitt et al., 1996). In the present study no differences were observed in 
any reproductive end point evaluated in dairy goats when receiving or not hCG. There are few reports of the use of this gonadotropin in goats. In one study, a 250 IU dose was able to induce estrus in anestrous goats when administered $24 \mathrm{~h}$ before progestagen sponge removal $(6 \mathrm{~d}$ protocol; Fonseca et al., 2005). It was shown later that the $\mathrm{hCG}$ administration $5 \mathrm{~d}$ after breeding increased plasma progesterone concentrations on Days 13 to 21 but did not increase pregnancy rate (Fonseca et al., 2006). The dose of 250IU hCG was arbitrary and represents one-tenth of the effective dose used in cattle (2000 to $3000 \mathrm{IU}$ ). In our study we used the same dose as before (Fonseca et al., 2005; Fonseca et al., 2006), which is half what (250 vs 500 IU hCG) Saleh et al. (2012) used. Perhaps this dose is too low to use in dairy goats that have intense metabolism and other quantities should be investigated. Due to animal welfare, pharmaceutical companies and researchers worldwide are developing possible alternatives, based on reducing the length or the dose of treatments (Abecia et al., 2011). Therefore, it is essential to define the suitable dose for each reproductive category in order to use a minimal but efficient dose to reach the purposes.

The number of does in estrus after the first PGF administration observed in this study was $76 \%$ $(22 / 29)$, similar to those related by Goel and Agrawal (1998), who reported $75 \%$ in Jakhrana lactating goats. A similar percentage was obtained after the second dose $(79 \% ; 23 / 29)$. However, the interval to estrus after the first dose (75.8h) was significantly longer than after the second dose of PGF (47.7h). The estrus duration was also different for the first $(35.4 \mathrm{~h})$ or second (26.8h) estrus. These data show that even if the number of does in estrus was similar after the first or second dose, the differences for interval to estrus and estrus duration indicate that a greater synchronization was achieved after the second dose of PGF. This is probably the most desired feature when working with Artificial Insemination in commercial dairy goat systems. Another element to support this assumption is that functional corpus luteum was present in all does at the moment of the second PGF dose, as evidenced by progesterone shown in Fig. 2, different from the progesterone profile after the first dose. The presence of an active corpus luteum at the time of the PGF administration is the key point to determine the success of estrus synchronization. Animals with progesterone inferior to $1 \mathrm{ng} / \mathrm{mL}$ at this time could have been in estrus before (two or three days) or entering in estrus at the moment of PGF administration (Fonseca et al., 2012). Some studies described in literature aim to use protocols to assess which does have supraluteal concentrations before administrating PGF in order to be sure corpora lutea will be present and thus does will respond to the treatment. For example, does were observed for estrus signs and $4 \mathrm{~d}$ later progesterone analysis was performed. Just when concentrations exceeded $5 \mathrm{ng} / \mathrm{mL}$, dinoprost was administered (Saleh et al., 2012). This kind of protocol is interesting to achieve a higher estrous response after PGF administration; however, this may not be feasible for commercial systems.

The interval to estrus currently reported after the second dose $(\sim 48 \mathrm{~h})$ is similar to previous studies which obtained $50 \mathrm{~h}$ (Fonseca et al., 2012) or 46h (Siqueira et al., 2012) and shorter than 65h, reported by Goel and Agrawal (1998). This is probably a result of the administration route. Mellado et al. (1994) reported a shorter interval from prostaglandin administration to the onset of estrus by comparing the use of intra-vulvo submucosal to the results of intramuscular route. In the present study, all does presenting estrus ovulated, with anoverall ovulation rate of $79 \%$ (23/29). A similar percentage (80\%) was reported in the Alpine breed (Fonseca et al., 2010). The number of ovulations averaged 1.8, similar to that reported by our group in Saanen goats in Alpine (1.7; Fonseca et al., 2010) or Toggenburg breed (1.7; Souza et al., 2011).

The pregnancy rate of goats receiving or not hCG averaged $61 \%(14 / 23)$ after AI. This protocol of a 10 day interval of PGF administrations is effective in synchronizing estrus, but the fertility of females at first mating is lower than that after progestagen treatments and natural services. Possible causes for such decreased conception rate remain unclear. A previous study in goats pointed to alterations in the functionality of preovulatory follicles (Fernandez-Moro et al., 2008). Vázquez et al. (2010) revealed deficiencies in the growth and functionality of luteal tissue in goats treated with prostaglandin analogue. The authors demonstrated that corpora lutea of treated does with regular length cycles were larger in size than those of untreated-goats, but showed a 
lower secretion of progesterone and a weakened effect on dynamics and lifespan of dominant follicles growing during the mid-luteal phase. Apparently the explanation for this drop in fertility is that, by using a 10 day interval, the presence of a CL is assured, but it may induce a disruption of ovulatory follicular dynamics, disturbing functionality and final maturation of the preovulatory follicles and normal luteogenesis, and/or a variability in the timing of ovulation after PGF induced luteolysis (Abecia et al., 2011; Abecia et al., 2012).

\section{CONCLUSIONS}

The hormonal possibilities to control reproduction in small ruminants are well reported and could be useful tools to increase farm profitability. The limitation of the use of progestagens may favour the use of prostaglandins for application of assisted reproductive techniques, but protocols based on these hormones are yet to be improved. The attempt to achieve enhanced results with $250 \mathrm{IU}$ hCG was not successful. Until a solution for the problem is found, it is advisable to inseminate prostaglandin-synchronized does $16 \mathrm{~h}$ after the onset of detected estrus.

\section{ACKNOWLEDGMENTS}

The authors were supported by the National Council for Scientific and Technological Development (Capes), Fluminense Federal University/Fopesq, Faperj. The authors wish to thank Dr. Eunice Oba for progesterone analysis; and the invaluable help of Dr. Marlene Bruschi from the Granja Água Limpa farm, Piau, Minas Gerais and Dr. Maria Pia Guimarães from the Granja Sanri, Florestal, Minas Gerais, Brazil. This study was also supported by the National Council for Scientific and Technological Development (CNPq; Project 559151/2010-1) and Brazilian Agriculture Research Corporation (EMBRAPA; Project 02.08.02.005.00.04). JFF, EO and FZB are CNPq fellows.

\section{REFERENCES}

ABECIA, J.A.; FORCADA, F.; GONZÁLEZBULNES, A. Pharmaceutical Control of Reproduction in Sheep and Goats. Vet. Clin. Food Anim., v.27, p.6779, 2011.
ABECIA, J.A.; FORCADA, F.; GONZÁLEZBULNES, A. Hormonal control of reproduction in small ruminants. Anim. Reprod. Sci., v.130, p.173-179, 2012.

FERNANDEZ-MORO, D.; VEIGA-LOPEZ, A.; ARIZNAVARRETA, C. et al. Preovulatory follicle developmentin goats following oestrous synchronization with progestagensor prostaglandins. Reprod. Dom. Anim., v.43, p.9-14, 2008.

FONSECA, J.F.; ALVIM, G.P.; LOBO, A.M.B.O. et al. Técnica Embrapa de inseminação Artificial transcervical em caprinos por meio de fixação cervical. Circular Técnica Número 43. Embrapa Caprinos e Ovinos, 2011. Disponível em: <http://www.infoteca.cnptia.embrapa.br/bitstream/doc 1921532/1/CT43.pdf>. Acessado em: 13 ago. 2012.

FONSECA, J.F.; BRUSCHI J.H.; ZAMBRINI F.N. et $a l$. Induction of synchronized estrus in dairy goats with different gonadotrophins. Anim. Reprod., v.2, p.50-53, 2005 .

FONSECA, J.F.; MAFFILI, V.V.; RODRIGUES, M.T. et al. Effects of hCG on progesterone concentrations and fertility in cyclic, lactating Alpine goats. Anim. Reprod., v.3, p.410-414, 2006.

FONSECA, J.F.; MAFFILI, V.V.; SANTOS, A.D.F. et al. Effects of prostaglandin administration 10 days apart on reproductive parameters of cyclic dairy nulliparous goats. Arq. Bras. Med. Vet. Zootec., v.64, p.349-358, 2012.

FONSECA, J.F.; SOUZA, J.M.G.; BRUSCHI, J.H. et al. Induction of estrus in cyclic Alpine goats with short-term progesterone protocols with or without eCG administration. In: ANNUAL CONFERENCE OF THE INTERNATIONAL EMBRYO TRANSFER SOCIETY, 36., 2010, Cordoba. Proceedings... Sidney: Reproduction, Fertility and Development, 2010. v.22. p.169.

GINTHER, O.J.; KOT, K. Follicular dynamics during the ovulatory season in goats. Theriogenology, v.42, p.987-1001, 1994.

GOEL, A.K.; AGRAWAL, K.P. Oestrus synchronization in cyclic goats following lutalyse administration. J. Anim. Sci., v.68, p.155-156, 1998.

MARTINS, G.; IGUEIRA, L.M.; PENNA, B. et al. Prevalence and antimicrobial susceptibility of vaginal bacteria from ewes treated with progestin-impregnated intravaginal sponges. Small Rum. Res., v.81, p.182184, 2009.

MELLADO, M.; ALEMÁN, R.; OROZCO, F.J. Effect of prostaglandin dosage and route of administration on estrous response in Criollo goats under range conditions. Small Rum. Res., v.14, p.205-208, 1994. 
NATIONAL research council - NRC. 6.ed. Nutrient requirements of small ruminants: sheep, goats, cervids, and new worlds camelids. Washington: National Academic Press, 2007. 384p.

SALEH, M.; SHAHIN, M.; WUTTKE, W. et al. Pharmacokinetics of human chorionic gonadotropin (hCG) after intramuscularadministration in goats (Capra hircus). Reproduction, v.144, p.77-81, 2012.

SAHARREA A.; VALENCIA J.; BALCÁZAR A. et al. Premature luteal regression in goats superovulated with PMSG: effect of hCG or GnRH administration during the early luteal phase. Theriogenology, v.50, p.1039-1052, 1998.

SIQUEIRA, A.P.; OLIVEIRA, R.M.P.; SILVA FILHO, J.M. et al. Progesterona plasmática e fertilidade de fêmeas caprinas submetidas à sincronização do estro com prostaglandina F2 $\alpha$. Arq. Bras. Med. Vet. Zootec., v.64, p.305-310, 2012.

SCHMITT, E.J.; BARROS, C.M.; FIELDS, P.A. et al. A cellular and endocrine characterization of the original and induced corpus luteum after administration of a gonadotropin-releasing hormone agonist or human chorionic gonadotropin on day five of the estrous cycle. J. Anim. Sci., v.74, p.19151929, 1996.
SOUZA, J.M.G.; TORRES, C.A.A.; MAIA, A.L.R.S. et al. Autoclaved, previously used intravaginal progesterone devices induces estrus and ovulation in anestrous Toggenburg goats. Anim. Reprod. Sci., v.129, p.50-55, 2011.

SUITER, J. Body condition scoring in sheep and goats. Farmnonte 69/94. Disponível em: <http://www.agric.wa.gov.au/content/aap/sl/m/fn069_ 1994.htm>, 1994. Acessado em: 23 Set. 2010.

VÁZQUEZ, M.I.; BLANCH, M.S.; ALANIS, G.A. et al. Effects of treatment with a prostaglandin analogue on developmentaldynamics and functionality of induced corpora lutea in goats. Anim. Reprod. Sci., v.118, p.42-47, 2010. 